\title{
AN ANALYTICAL STUDY OF HOMICIDAL DEATHS AUTOPSIED
}

\author{
Bandameedi Lakshmi Narayana1, Yerukala Komera Chinna Rangaiah², Mohammed Abdul Khalid ${ }^{3}$ \\ 1 Professor and HOD, Department of Forensic Medicine, Kurnool Medical College, Kurnool, Andhra Pradesh. \\ ${ }^{2}$ Assistant Professor, Department of Forensic Medicine, Kurnool Medical College, Kurnool, Andhra Pradesh. \\ ${ }^{3}$ Assistant Professor, Department of Forensic Medicine, Viswabharathi Medical College, R.T. Nagar, \\ Near K. Nagalapuram, Kurnool, Andhra Pradesh.
}

\section{ABSTRACT}

Homicide is the most heinous and often the most violent crime committed against a person by another person. Incidence of homicide is increasing day by day and is becoming a major threat to the harmony of society. In the present study, homicidal deaths occurred over a period of 5 years, i.e. from 2008 to 2012 in and around Tirupati region were analysed. During the study period, the incidence of homicidal deaths was $4.02 \%$ with a male-to-female ratio of 1.96:1. Most common age group to be involved was 30-39 years. The most frequent method of homicide was use of blunt weapons (38.03\%), followed by use of sharp weapons (25.15\%), asphyxial methods (11.03\%). Personal enmity (20.24\%), extramarital affairs (18.40\%), love affairs (18.49\%) and financial disputes $(12.26 \%)$ were among the common motives behind the act. Incidence of homicide was more common during night times (56.98\%) and at place of living of victim or assailant (43.55\%). Most of the victims (85.88\%) remained totally deprived of any medical help.

\section{KEYWORDS}

Forensic Medicine/Homicide, Age and Sex, Motive, Weapons used, Tirupati.

HOW TO CITE THIS ARTICLE: Narayana BL, Rangaiah YKC, Khalid MA. An analytical study of homicidal deaths autopsied. J. Evolution Med. Dent. Sci. 2016;5(13):540-543, DOI: 10.14260/jemds/2016/124

\section{INTRODUCTION}

"Homicide is defined as the killing of one human being by the act, procurement or omission of another and the term applies to all such killings whether criminal or not."(1) "Homicide is prevalent widely almost all over the world."(2) Murder of an opponent for various reasons is one of the oldest tools of power struggles from Stone Age.(3)

Globally around 520,000 people die each year as a result of interpersonal violence, which equates to 1400 deaths every single day.(4) Homicide is the 6th leading cause of death in the age group 15-29 years and 7th leading cause of death in the age group 30-44 years. ${ }^{(5)}$ Incidence of homicide is increasing day by day, probably due to rapid rise in population, industrialization, internationalization, growing unemployment, stressful life, depression in day-to-day life, lack of harmony in family members, drug addiction and sociopolitical factors. The incidence and method of homicide differs from country to country and region to region.

Therefore, homicide should be taken as a public health issue and emphasis has to be laid on reliable data and surveillance mechanisms, so that we can bring a practical and simple approach to homicide prevention.

The pattern of homicide may be a useful indicator of the social stresses in a community and may also provide useful information for the law enforcement agencies. Several workers have tried to elucidate the different aspects of homicidal deaths in various parts of the world and in India also. As there is no previous literature or study on the mortality profile of homicidal cases from this region, the present study was undertaken to study these aspects.

Financial or Other, Competing Interest: None.

Submission 30-12-2015, Peer Review 25-01-2016,

Acceptance 30-01-2016, Published 12-02-2016.

Corresponding Author:

Dr. B. Lakshmi Narayana,

Professor and HOD, Department of Forensic Medicine,

Kurnool Medical College, Kurnool.

E-mail: hodfmkmcknl@gmail.com

DOI: $10.14260 /$ jemds/2016/124

\section{MATERIALS AND METHODS}

The present study is a retrospective analysis of medico-legal autopsies conducted in Department of Forensic Medicine, Sri Venkateswara Medical College Tirupati from 2008 to 2012 with an alleged history of homicide. Postmortem reports of victims of homicide, police inquest reports, medical records if available, crime scene photographs and history collected from family members, relatives and friends were studied to analyse the factors such as Age and Sex of victims, Method of homicide, Weapons used, Motive for such acts, Place of occurrence, Time of occurrence, etc. involved with the homicide.

\section{OBSERVATIONS}

Total number of medico-legal cases autopsied at Sri Venkateswara Medical College, Tirupati, during 2008 to 2012 was 4047 of which $163(4.02 \%)$ cases were with history of homicide (Table 1). Commonest age group to be affected was $30-39$ years (28.2\%), followed by $20-29$ years $(25.7 \%)$. In all age groups males were affected more than females, except in 20-29 years age group and 0-9 years' age group (Table 2). Identity of the victims was not known in $7.97 \%$ of cases. Maleto-female ratio was 1.96:1.

About $70 \%$ of the victims were married, whereas marital status was not known in $7.97 \%$ of cases and was not applicable for $9.20 \%$ of cases (below the age group of 20 years) (Table 3). Most of the cases occurred during the late evening and night times (34.90\%) (Table 4) and place of occurrence was mostly home (43.55\%), followed by agricultural fields (19.63\%) (Table 5). Blunt trauma (38.03\%) was the most common method of homicide, followed by trauma with sharp weapons (25.15\%) (Table 6). Revenge or personal enmity was the leading motive (20.24\%), followed by extramarital affairs $(18.40 \%)$, love affairs $(13.49 \%)$ and financial matters $(12.26 \%)$ (Table 7$)$. More than half of the victims (56.44\%) belonged to rural background and majority did not get any sort of medical assistance (85.88\%) after the incident (Table 8). 


\begin{tabular}{|c|c|c|c|}
\hline Year & $\begin{array}{c}\text { Total } \\
\text { Postmortems }\end{array}$ & $\begin{array}{c}\text { Cases of } \\
\text { Homicides }\end{array}$ & Percentage \\
\hline 2008 & 761 & 30 & 3.94 \\
\hline 2009 & 747 & 26 & 3.48 \\
\hline 2010 & 893 & 37 & 4.14 \\
\hline 2011 & 834 & 41 & 4.91 \\
\hline 2012 & 812 & 29 & 3.57 \\
\hline \multicolumn{3}{|c|}{ Table 1: Incidence of Homicide } \\
\hline
\end{tabular}

\begin{tabular}{|c|c|c|}
\hline Time & No. of Cases & Percentage \\
\hline 00:01 AM to 06:00 AM & 36 & 22.08 \\
\hline 06:01 AM to $12: 00$ Noon & 16 & 9.81 \\
\hline 12:01 PM to 06:00 PM & 45 & 27.60 \\
\hline 06:01 PM to 00:00 AM & 57 & 34.90 \\
\hline Not known & 09 & 5.52 \\
\hline \multicolumn{3}{|c|}{ Table 4: Time of Occurrence } \\
\hline
\end{tabular}

\begin{tabular}{|c|c|c|c|}
\hline \multirow{2}{*}{$\begin{array}{c}\text { Age Group } \\
\text { (Years) }\end{array}$} & Male & Female & \multirow{2}{*}{ Total (\%) } \\
\cline { 2 - 4 } & 01 & 05 & $06(3.68)$ \\
\hline $0-9$ & 05 & 04 & $09(5.52)$ \\
\hline $10-19$ & 20 & 22 & $42(25.70)$ \\
\hline $20-29$ & 35 & 11 & $46(28.20)$ \\
\hline $30-39$ & 30 & 08 & $38(23.30)$ \\
\hline $40-49$ & 07 & 02 & $09(5.52)$ \\
\hline $50-59$ & 05 & 02 & $07(4.29)$ \\
\hline $60-69$ & 05 & 01 & $06(3.68)$ \\
\hline 70 and above & $\mathbf{1 0 8}$ & $\mathbf{5 5}$ & $\mathbf{1 6 3}$ \\
\hline \multicolumn{3}{|c|}{ Table 2: Age groups of victims } \\
\hline \multicolumn{4}{|c}{} \\
\hline
\end{tabular}

\begin{tabular}{|c|c|}
\hline Place of Occurrence & No. of Cases (\%) \\
\hline Home & $71(43.55)$ \\
\hline Fields & $32(19.63)$ \\
\hline Work place & $17(10.42)$ \\
\hline Road side & $17(10.42)$ \\
\hline Forest & $11(06.74)$ \\
\hline Market & $09(06.13)$ \\
\hline Bus stand & $03(01.84)$ \\
\hline Temple premises & $02(01.22)$ \\
\hline Hospital premises & $01(00.61)$ \\
\hline \multicolumn{2}{|c|}{ Table 5: Place of Occurrence } \\
\hline \multicolumn{2}{|c}{} \\
\hline
\end{tabular}

\begin{tabular}{|c|c|c|c|c|}
\hline \multicolumn{2}{|c|}{ Characteristic } & \multicolumn{2}{|c|}{ No. of Cases } & \multirow{2}{*}{ Total (\%) } \\
\cline { 2 - 5 } & Male & Female & \\
\hline \multirow{2}{*}{ Identity } & Known & 99 & 51 & $150(92.02)$ \\
\cline { 2 - 5 } & Unknown & 09 & 04 & $13(7.97)$ \\
\hline \multirow{4}{*}{$\begin{array}{c}\text { Marital } \\
\text { Status }\end{array}$} & Married & 77 & 36 & $113(69.32)$ \\
\cline { 2 - 5 } & Unmarried & 16 & 06 & $22(13.49)$ \\
\cline { 2 - 5 } & Unknown & 09 & 04 & $13(07.97)$ \\
\cline { 2 - 5 } & $\begin{array}{c}\text { Not } \\
\text { applicable }\end{array}$ & 06 & 09 & $15(09.20)$ \\
\hline \multicolumn{3}{|c|}{ Table 3: Identity and Marital Status of the victim } \\
\hline
\end{tabular}

\begin{tabular}{|c|c|}
\hline Method & No. of Cases (\%) \\
\hline Blunt trauma & $62(38.03)$ \\
\hline Sharp trauma & $41(25.15)$ \\
\hline Blunt + Sharp trauma & $24(14.72)$ \\
\hline Burns & $13(07.97)$ \\
\hline Ligature strangulation & $10(06.13)$ \\
\hline Manual strangulation & $08(04.90)$ \\
\hline Poisoning & $04(02.45)$ \\
\hline Firearms & $01(00.61)$ \\
\hline \multicolumn{2}{|c|}{ Table 6: Method of Homicide } \\
\hline
\end{tabular}

Table 3: Identity and Marital Status of the victim

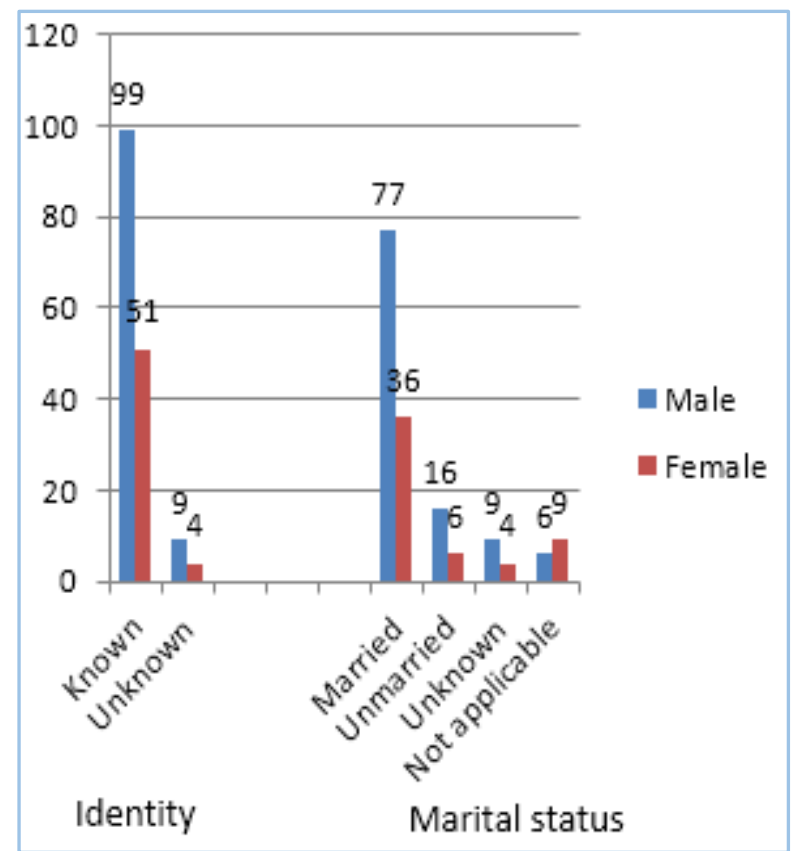

Fig. 1: Identity and Marital status of the victims

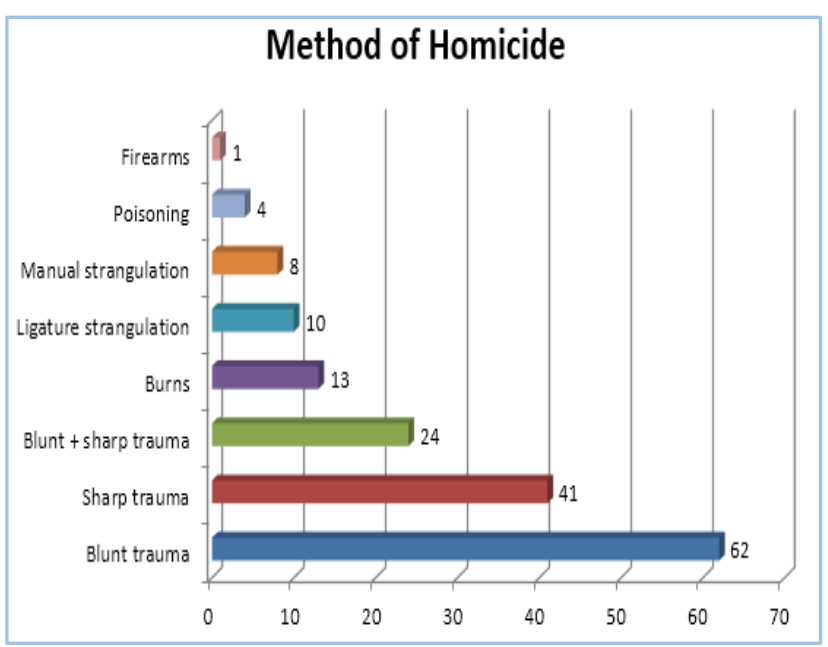

Fig. 2: Method of Homicide

\begin{tabular}{|c|c|c|c|}
\hline \multirow{2}{*}{ Motive } & \multicolumn{2}{|c|}{ Sex } & \multirow{2}{*}{$\begin{array}{c}\text { No. Cases } \\
\text { (\%) }\end{array}$} \\
\cline { 2 - 4 } & Male & Female & $33(20.24)$ \\
\hline Revenge & 25 & 08 & $30(18.40)$ \\
\hline Extra marital affair & 19 & 11 & $22(13.49)$ \\
\hline Love affair & 09 & 13 & $20(12.26)$ \\
\hline Financial matters & 15 & 05 & $16(09.81)$ \\
\hline Property disputes & 12 & 04 & $15(09.20)$ \\
\hline Petty quarrels & 13 & 02 & $11(06.74)$ \\
\hline $\begin{array}{c}\text { During theft/ } \\
\text { robbery }\end{array}$ & 06 & 05 & $03(01.84)$ \\
\hline Dowry related & -- & 03 & $13(07.97)$ \\
\hline Not known & 09 & 04 & \\
\hline \multicolumn{4}{|c|}{ Table 7: Motive for Homicide } \\
\hline
\end{tabular}




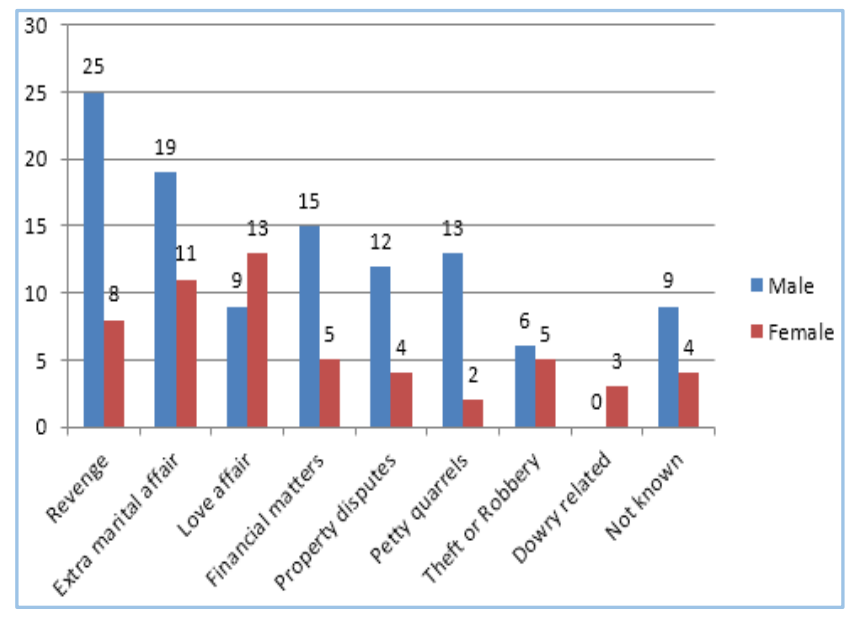

Fig. 3: Motive for Homicide

\begin{tabular}{|c|c|c|c|}
\hline \multirow{2}{*}{ Characteristic } & \multicolumn{2}{c|}{ No. of Cases } \\
\cline { 2 - 4 } & Rural & 62 & Males \\
\hline \multirow{3}{*}{ Habitat } & Urban & 33 & 25 \\
\cline { 2 - 4 } & Not known & 8 & 5 \\
\hline \multirow{2}{*}{$\begin{array}{c}\text { Medical } \\
\text { Care }\end{array}$} & Received & 10 & 13 \\
\cline { 2 - 4 } & $\begin{array}{c}\text { Not } \\
\text { received }\end{array}$ & 98 & 42 \\
\hline \multicolumn{3}{|c|}{$\begin{array}{c}\text { Table 8: Habitat of victims } \\
\text { and Medical care details }\end{array}$} \\
\hline
\end{tabular}

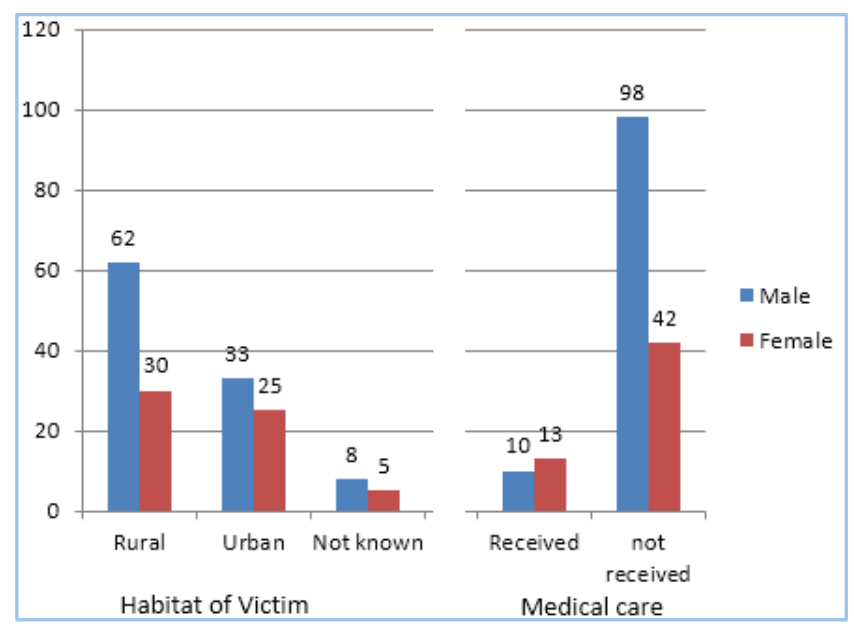

Fig. 4: Habitat and Medical care details

\section{DISCUSSION}

In the present study, out of 4047 medico-legal cases autopsied at SVMC, Tirupati, 163 cases (4.02\%) were of alleged homicidal deaths. The incidence of homicide in the present study was lower when compared to those observed by Murthy et al.(6) 15.1\%, Gupta et al.(7) 7.5\%, Sinha et al.(8) 5.9\%, Dhaval.(9) $9.13 \%$ and B.C. Shiva Kumar et al.(3) $4.76 \%$, whereas it was consistent with studies of Prajapati et al.(10) $4.12 \%$ and 0. Gambhir.(11) 2.89\%.

Homicides were commonly seen in the fourth decade followed by third decade of life. This observation goes in favour that homicides involve the age group, which is in most active and productive period of life. In this study personal enmity/revenge, extramarital affairs and love affairs came out as the major motives behind the act which indicates that the victims were mostly married well into the lives or were getting into the love affairs because of this age.
People of 20-29 years age group are violent and more vulnerable to fast changing social trends, ending up in misunderstanding, frustration, hatred, etc. The present study goes along with the study of Rekhi et al.(12) and Wahlsten et al.(13) who reported 31-40 years as the most commonly involved age group. However, the present study contradicts the finding of Murthy et al.(6) Gupta et al.(2) and Prajapati et al.(10) In the present study, M:F ratio was 1.96:1. Similar findings were also observed in various other studies like Murthy et al.(6), Prajapati et al.(10)

This is because males are more aggressive, violent, bread earners have more opportunity for interpersonal interactions. Generally, women and children are spared off even in case of revenge, whereas males are the main target. Out of 163 cases, $69.32 \%$ of the victims were married and marital status was not known in $7.97 \%$ cases and was considered as not applicable in 15 cases $(9.20 \%)$ (Age was less than 19 years). The findings are consistent with the works of Dhaval.(9) (69.62\%) and 0. Gambhir.(11) Family disputes, financial burdens, lack of understanding between the spouses and other family members having extramarital affairs are the reasons for very high incidence of homicide among married people when compared to unmarried persons.

Majority of cases (34.9\%) have occurred between $6 \mathrm{pm}$ to 12 midnight. These findings were consistent with those of Dhaval.(9) and Sinha et al.(8), whereas Bhupinder S et al.(14) and B.C. Shiva Kumar.(3) reported the incidence to be more between 6 AM - 12 PM. As darkness of night provides favourable conditions and easy execution and escape for the accused, it is more preferred. Personal enmity or revenge was the major motive behind the homicidal act (20.24\%), followed by extramarital affairs, financial matters, property disputes, petty quarrels and during robbery or theft. In $7.97 \%$ cases motive was not known. The findings are consistent with Dhaval.(9) (29.4\%), B. C. Shiva Kumar et al.(3) (32.5\%), whereas financial matters were reported as a major reason for homicide by Sinha et al.(8)

In this study, the commonest weapon of choice was blunt and hard weapons (38.03\%), followed by sharp weapon $(25.15 \%)$. The findings are consistent with the studies of Dhaval.(9) (32.5\%) and Prajapati et al.(10) where blunt weapon was commonest but contradict with the studies of B. C. Shiva Kumar et al.(3) (50\%) and Vij et al.(15) (49.4\%), where sharp weapon was commonest. Easy availability of hard and blunt objects and as most of the cases were not premeditated the blunt weapon was the choice of majority of the accused. Poisoning $(2.45 \%)$ and firearms $(0.61 \%)$ were the least reported methods of homicide.

In majority of cases place of living of either the victim or accused or of some other relative itself became the place of ill fate (43.55\%), this is followed by agricultural fields (19.63\%) and work place $(10.42 \%)$. As most interactions take place at home and work place, they accounted as the major sites of homicidal acts. The study shows similarity with that of Rodge et al.(16) whereas contradicts with the study of Dhaval.(9) and B. C. Shiva Kumar.(3) where outdoors was the major site of homicidal act. In majority of cases the victims did not get any medical help (85.88\%): only a minor group of victims received medical help (14.11\%). This shows that in most cases the victims were seen to death by the assailants and majority of them occurring during night hours hampered the chances of medical help. 
The other reasons being the place of incidence, fear of getting involved in litigation by the common people leaving the victim to his/her own fate. This finding is in consistence with the study of A. Karn et al.(17) Homicides were more common in rural population $(60.73 \%)$ when compared to urban population. Reason for this being, rural habitat of majority of the study population and existence of faction feuds and groups in the rural areas. Similar results were seen in the study by A. Karn et al.(17)

\section{CONCLUSION}

Out of 163 homicidal death cases, age group of 21-40 years was mostly affected with a male-to-female ratio of 1.96:1. About $70 \%$ of the victims were married and most cases of homicide took place during evening and early night hours. Revenge/personal enmity was the main motive with extramarital affairs being in second place. Blunt weapon was the commonest weapon of choice with most of the homicides taking place at the home of victim or assailant or some relative, i.e. indoors itself. Only a few victims received medical help.

Homicide is one of the worst forms of crime as no one has the right to take the life of an individual. Socioeconomic wellbeing, removal of poverty and enhanced employment opportunities will help to check the incidence of homicides. Importance of ethical and moral values should be taught to the children in schools itself, which will help in strengthening of human relationships. Overall, law and order of the state has to be strong to minimize such cases in the future.

\section{REFERENCES}

1. Koehler SA, Brown PA. International Forensic Science and Investigations Series- Forensic Epidemiology. Boca Raton: CRC Press; 2010;187

2. Gupta S and Prajapati P. Homicide trends at Surat Region of Gujarat, India J of Forensic Medicine \& Toxicology, 2009;26(1):45-48.

3. Shiva Kumar BC, Vishwanath D, Srivastava PC. Trends of homicidal deaths at a tertiary care centre, Bengaluru. J Indian Acad Forensic Med. April-June 2011;33(2):120124.
4. Preventing violence. A guide to implementing the recommendations of the world report on violence and health. Geneva: World Health Organization, 2004.

5. Global burden of disease, 2002, leading causes of death. WHO bulletin.

6. Murthy OP, Krong KS, Ghazali MF, et al. Study of homicidal deaths at University Malaya Medical Centre, Kuala Lumpur. International Journal of Medical Toxicology and Legal Medicine, 2005;7(2):4-9.

7. Gupta A, Mukta R, Mittal AK, et al. A study of homicidal deaths in Delhi. Med Sci Law 2004;44(2):127-32.

8. Sinha US, Kapoor AK and Pandey SK. Pattern of homicidal deaths in SRN Hospital's mortuary at Allahabad. J Forensic Med Toxicology, 2003;20(2):33-36.

9. Dhaval J Patel. Analysis of homicidal deaths in and around Bastar region of Chhattisgarh. J Indian Acad Forensic Med. April-June 2012;34(2):139-42.

10. Prajapati P, Sheikh MI and Patel S. Study of homicidal deaths by mechanical injuries in Surat, Gujarat. J Indian Acad Forensic Med 2010;32(2):134-38.

11. Gambhir $O$ and Gupta BD. Evaluation of mechanical injury in homicidal deaths; J Indian Acad Forensic Med 2007;23(3):18-22.

12. Rekhi T, Singh KP and Nabachandra H. Study on homicidal blunt force injuries. J Forensic Med \& Toxicology 2007;24(2):3-5.

13. Waslsten P, Koiranen V and Saukko P. Survey of medicolegal investigation of homicide in the city of Turku, Finland. J Forensic Legal Med 2007;14(2007):243-252.

14. Bhupinder S, Kumar TK and Syed AM. Pattern of homicidal deaths autopsied at Penang Hospital, Malaysia, 2007-2009. A preliminary study. Malaysian J Pathol 2010;32(2):81-86.

15. Vij A, Menon A, Menezes RG, et al. A retrospective review of homicides in Mangalore, South India. J Forensic and Legal Med 2010;17(6):312-15.

16. Rodge S, Hougen HP and Poulsen K. Homicide by blunt force in two Scandinavian capitals. Am J Forensic Med Pathol 2003;24(3):288-291.

17. Karn A, Jha S, Yadav BN, et al. Medico-legal study of suspected homicide cases in a Teaching Hospital in Eastern Nepal, Health Renaissance, Jan-April 2011;9(1):15-19. 